\title{
Preferencje podatkowe jako konstrukcje prawne w zakresie unikania podwójnego opodatkowania w ramach podatku od spadków i darowizn
}

Występowanie bądź istnienie konkretnych stanów faktycznych związane jest $\mathrm{z}$ przestrzeganiem szeregu norm prawnych określonych w systemie prawa. Sytuacje te powodują zróżnicowane, wyrażone m.in. normami prawa cywilnego ${ }^{1}$, stosunki o charakterze zobowiązaniowym. Również oznaczone stany faktyczne powodują przymusową powinność zobowiązaniową w zakresie zapłaty danin publicznych. $Z$ kolei pobór danin publicznych, możliwy na podstawie ustawy zasadniczej $^{2}$, nie ogranicza zarówno ich charakteru, jak i skali³. Należy jednak zaznaczyć, że zasady konstytucyjne ${ }^{4}$ mają na celu bezwzględne ograniczenie wobec stanowiących prawo, aby granice opodatkowania ${ }^{5}$ nie przybierały formy, w której podatki płacone są za wszystko i od wszystkich. Warto zaznaczyć, że literatura przedmiotu wiąże historyczny rozwój podatków z rozwojem gospodarki oraz kształtowaniem się struktur społecznych i politycznych społeczeństw ${ }^{6}$.

Godne uwagi są słowa brytyjskiej premier Margaret Thatcher, według której podatki są prostą propozycją, związaną z możliwością mieszkania w danym kraju, co z kolei wymusza konieczność zapłaty za ten przywilej. Takie ujęcie instytucji prawnej podatku powoduje, że rola więzi między podatnikami a państwem zyskuje na znaczeniu. Literatura przedmiotu postrzega podatki jako świadczenia jednostek na rzecz ogółu?

* Mgr Marek Klink - Katedra Prawa Finansowego, Wydział Prawa, Administracji i Stosunków Międzynarodowych, Krakowska Akademia im. Andrzeja Frycza Modrzewskiego.

${ }^{1}$ Ustawa z dnia 23 kwietnia 1964 r. Kodeks cywilny, Dz. U. Nr 16, poz. 93 ze zm.

2 Konstytucja Rzeczypospolitej Polskiej z dnia 2 kwietnia 1997 r., Dz. U. Nr 78, poz. 483 ze zm.

${ }^{3}$ Por. art. 217 Konstytucji RP.

${ }^{4}$ Por. T. Dębowska-Romanowska, Prawo finansowe. Część konstytucyjna wraz z częścia ogólna, Warszawa 2010, s. 145-147 oraz B. Banaszak, Konstytucja Rzeczypospolitej Polskiej. Komentarz, Warszawa 2009, komentarz do art. 2, dostęp: Legalis.

${ }^{5}$ Por. szerzej: A. Gomułowicz, Zasada sprawiedliwości podatkowej, Warszawa 2001.

${ }^{6}$ R. Mastalski, Prawo podatkowe, Warszawa 2006, wyd. 4, s. 3.

7 Ibidem, s. 3-4. 
Ustawodawca stosuje powszechnie występujące w konstrukcjach prawnych podatków instytucje służące przeciwdziałaniu podwójnemu opodatkowaniu. Do nich należy zaliczyć wyłączenia podatkowe oraz instytucje zwolnień i ulg podatkowych. Warto zaznaczyć, że zróżnicowane konstrukcje prawne w zakresie przeciwdziałania podwójnemu opodatkowaniu mają charakter fakultatywny, ponieważ ich normatywne ujęcie zależy od woli ustawodawcy.

Poza przypadkami wskazanymi powyżej, występują też takie sytuacje, w których minister finansów zgodnie z przysługującą kompetencją na podstawie art. 22 $\S 1$ Ordynacji podatkowej z dnia 27 sierpnia 1997 r. ${ }^{8}$ wydaje rozporządzenie o zaniechaniu poboru podatku ${ }^{9}$. Fakt ten należy utożsamiać z preferencją podatkową jako stanem, który powoduje korzyść po stronie podatnika. Organizacja w Polsce „UEFA EURO 2012” zawiera w sobie aspekt nie tylko sportowy, lecz również finansowy, co z kolei rodzi konieczność zapłaty danin publicznych. Jednak w tym przypadku poprzez rozporządzenie ministra finansów w określonych sytuacjach zaniechany został pobór podatków ${ }^{10}$.

Ustawa z dnia 28 lipca 1983 r. o podatku od spadków i darowizn ${ }^{11}$ zawiera rozwiązania prawne mające na celu przeciwdziałanie podwójnemu opodatkowaniu. Godny podkreślenia jest pogląd doktryny, według którego obciążenie podatkiem od spadków i darowizn uznawane jest z punktu widzenia podatników za bardzo wysokie ${ }^{12}$. Należy również zaznaczyć, iż w świetle nowelizacji obowiązującej od 1 stycznia 2007 r. ${ }^{13}$ niektóre grupy podatników stały się niezwykle uprzywilejowane.

Podatek od spadków i darowizn w swoim zakresie podmiotowym obejmuje jedynie osoby fizyczne nabywające pod określonymi enumeratywnie tytułami prawnymi ${ }^{14}$ rzeczy znajdujące się na terytorium Rzeczypospolitej Polskiej lub prawa majątkowe wykonywane na terytorium $\mathrm{RP}^{15}$. Jednak w pewnych przypadkach, zgodnie z regulacją zawartą w art. 2 ustawy o podatku od spadków i darowizn, nabycie własności rzeczy znajdujących się poza granicami Rzeczypospolitej

8 T.j. Dz. U. z 2005 r. Nr 8, poz. 60 ze zm.

9 Por. rozporządzenie Ministra Finansów z dnia 27 września 2006 r. w sprawie zaniechania poboru podatku dochodowego od osób fizycznych od niektórych dochodów (przychodów), Dz. U. $\mathrm{Nr} 183$, poz. 1359.

10 Por. rozporządzenie Ministra Finansów z dnia 28 lutego 2011 r. w sprawie zaniechania poboru podatku dochodowego od niektórych rodzajów dochodów (przychodów) podatników podatku dochodowego od osób prawnych i podatku dochodowego od osób fizycznych, Dz. U. Nr 52, poz. 267.

11 Dz. U. Nr 45, poz. 207; t.j. Dz. U. z 2009 r. Nr 93, poz. 768 ze zm.

12 Z. Ofiarski, Ustawa o podatku od spadków i darowizn. Komentarz, Warszawa 2002, dostęp: LEX.

13 Por. ustawa z dnia 16 listopada 2006 r. o zmianie ustawy o podatku od spadków i darowizn oraz ustawy o podatku od czynności cywilnoprawnych, Dz. U. Nr 222, poz. 1629.

14 Por. art. 1 ust. 1 pkt 1-6 ustawy o podatku od spadków i darowizn.

15 Por. art. 1 ust. 1 ustawy o podatku od spadków i darowizn. 
Polskiej lub praw majątkowych wykonywanych za granicą także podlega opodatkowaniu. Sytuacja ta ma miejsce, jeżeli w chwili otwarcia spadku lub zawarcia umowy darowizny nabywca był obywatelem polskim lub miał miejsce stałego pobytu na terytorium RP. W tym przypadku o stosowaniu określonych reguł prawnych decyduje, powiązany z czynnikiem czasu, status nabywcy oraz sposób nabycia, który został ograniczony do spadkobrania lub darowizny. Zauważyć należy, że zasada ta określa znacznie węższy zakres przedmiotowy opodatkowania niż stany faktyczne objęte zakresem przedmiotowym całej konstrukcji podatku od spadków i darowizn.

Godny uwagi pozostaje warunek, w oparciu o który ustawodawca przyjął conditio sine qua non opodatkowania podatkiem od spadków i darowizn, pozostający w związku z posiadaniem osobliwej zależności nabywcy z Rzecząpospolitą Polską. W tym przypadku priorytet ustawodawczy został związany z zasadą domicylu, która w konstrukcji podatku od spadków i darowizn posiada zakres zarówno terytorialny, jak i eksterytorialny. Zgodnie z zasadą domicylu podatkowego obowiązek podatkowy ciąży na osobie mającej miejsce stałego zamieszkania na terytorium Rzeczypospolitej Polskiej lub posiadającej obywatelstwo polskie ${ }^{16}$. Należy podkreślić, że określone zakresem przedmiotowym podatku od spadków i darowizn stany faktyczne podlegają opodatkowaniu tym podatkiem w sytuacji, gdy ich dokonanie ma miejsce na terytorium RP, a także w określonych przypadkach również poza tym terytorium. Należy zgodzić się ze stanowiskiem orzecznictwa, zgodnie z którym art. 1 oraz art. 2 ustawy o podatku od spadków i darowizn określają dwa samoistne, niezależne od siebie stany prawne, normujące odmienne stany faktyczne $\mathrm{w}$ zakresie przysporzenia majątkowego ${ }^{17}$. Pierwszy z nich związany jest z zakresem terytorium Rzeczypospolitej Polskiej, z kolei drugi, wykraczając poza ten zakres, wymaga spełnienia przesłanki w postaci posiadania obywatelstwa polskiego lub stałego pobytu na terytorium RP. W takim ujęciu obowiązywania ustawy o podatku od spadków i darowizn podatek ten nie jest ograniczony jedynie do czynności, których wynikiem jest określone nabycie rzeczy i praw majątkowych w granicach RP, lecz w określonych przypadkach będzie wykraczał poza ten zakres. Należy przy tym zaznaczyć, że konstrukcja podatku od spadków i darowizn nie jest wyłącznie polską domeną, bowiem zbliżone regulacje obowiązują $\mathrm{w}$ wielu państwach europejskich ${ }^{18}$.

W związku z narastającą migracją ludności obywatele Unii Europejskiej stają się coraz częściej nabywcami rzeczy i praw majątkowych zlokalizowanych w państwach, których ani nie są obywatelami, ani nie posiadają w nich miejsca

${ }^{16}$ Por. ustawę z dnia 15 lutego 1962 r. o obywatelstwie polskim, Dz. U. Nr 10, poz. 46; t.j. Dz. U. z 2000 r. Nr 28, poz. 353 ze zm.

17 Por. wyrok z dnia 6 maja 2008 r. WSA w Gdańsku, sygn. akt I SA/GD 1035/2007, „Monitor Podatkowy" 2009, nr 2, s. 4; LexPolonica 2149442.

18 Jedynie 9 państw spośród 27 należących do Unii Europejskiej nie posiada konstrukcji podatku od spadku lub majątku. 
zamieszkania. Konsekwencją tego typu sytuacji jest obowiązek zapłaty podatku zarówno w państwie, w którym znajdują się rzeczy lub też wykonywane są prawa majątkowe, jak i w Rzeczypospolitej Polskiej. Warto zaznaczyć, że zawierane przez RP umowy w zakresie zapobiegania podwójnemu opodatkowaniu dotyczą w swej materii podatków dochodowych, omijając tym samym stany faktyczne, podlegające opodatkowaniu podatkiem od spadków i darowizn. Ten stan został potwierdzony przez orzecznictwo Naczelnego Sądu Administracyjnego, zgodnie z którym umowy o unikaniu podwójnego opodatkowania nie zawierają reguł dotyczących podatku od spadków i darowizn ${ }^{19}$. Potwierdzeniem tej tezy jest zakres przedmiotowy, określony m.in. w Konwencji między Rzecząpospolitą Polską a Kanadą w sprawie unikania podwójnego opodatkowania i zapobiegania uchylaniu się od opodatkowania ${ }^{20}$, wymieniający oznaczone podatki ${ }^{21}$. Zakres ten $\mathrm{w}$ ramach polskiej kategoryzacji podatkowej obejmuje polski podatek dochodowy od osób fizycznych oraz polski podatek dochodowy od osób prawnych. Zaznaczyć należy, że Konwencja zawiera zapis mówiący, że podatki takiego samego lub podobnego rodzaju, które będą nakładane dopiero po dacie podpisania niniejszej Konwencji, objęte zostaną jej normami ${ }^{22}$. Wynikiem takiego stanu prawnego jest $\mathrm{z}$ reguły podwójne opodatkowanie nabywanych rzeczy lub praw majątkowych, bowiem polski podatek od spadków i darowizn nadal obowiązuje, jednocześnie nie należąc do zakresu przedmiotowego Konwencji. Jedynym czynnikiem powodującym korzyść po stronie podatnika podatku od spadków i darowizn jest umożliwienie zmniejszenia podstawy opodatkowania o podatek zapłacony za granicą, jako że stanowi on ciężar w myśl art. 7 ust. 1 ustawy o podatku od spadków i darowizn. Możliwość redukcji podstawy opodatkowania o podatek zapłacony za granicą stanowi przykład zastosowania instytucji ulgi podatkowej.

Szczególny charakter zasługujący na uwagę, będący wyjątkiem od praktyki podwójnego opodatkowania w ramach podatku od spadków i darowizn, stanowią umowy w zakresie unikania podwójnego opodatkowania zawarte pomiędzy Rzecząpospolitą Polską a jedynie trzema państwami, mianowicie: Austrią, Czechosłowacją oraz Węgrami. Zakres przedmiotowy tych międzynarodowych umów wiąże się z majątkowym charakterem podatku od spadków i darowizn, co potwierdza ich wyjątkowe znaczenie. Wymienione umowy określają jedynie reguły $\mathrm{w}$ zakresie unikania podwójnego opodatkowania w przypadku przeniesienia własności z powodu śmierci²3, ograniczając tym samym zakres ich stosowania.

19 Por. wyrok NSA z dnia 5 czerwca 2003 r., sygn. akt I SA/Wr 16/01.

${ }^{20}$ www.mf.gov.pl/_files_/podatki/umowy_miedzynarodowe/2012/kanada_konwencja_pl.pdf.

21 Por. art. 2 ust. 3.

${ }_{22}$ Por. art. 4 ust. 4.

${ }^{23}$ Por. art. 5 Konwencji z dnia 24 listopada 1927 r. między Rzecząpospolitą Polską a Republiką Austrjacką. 
Pierwsza z umów, tzn. Konwencja z dnia 24 listopada 1927 r. między Rzecząpospolitą Polską a Republiką Austrjacką ${ }^{24}$ o zapobieganiu dwukrotnemu pobieraniu podatku spadkowego ${ }^{25}$ określa sytuacje i właściwość krajową w zakresie stosowania prawa podatkowego. Zawiera ona dwie odmienne zasady, z których jedna dotyczy przypadku nabycia nieruchomości wraz z przynależnościami, z kolei druga z zasad ma zastosowanie do pozostałych przypadków. Zgodnie z art. 1 pkt 1 Konwencji z 1927 r.: „Nieruchomy majątek spadkowy, pozostały po obywatelach każdego z obydwóch Umawiających się Państw, wliczając doń i przynależności, podlega podatkowi spadkowemu tylko w tem Państwie, w którem się znajduje"26. Odmienne reguły dotyczą nabywanego majątku ruchomego oraz praw majątkowych. Zasada ogólna odnosząca się do nabywanego majątku nieruchomego określa, że majątek ten podlega podatkowi spadkowemu w tym kraju, w którym się znajduje. Zatem nabycie tytułem dziedziczenia przez obywatela polskiego nieruchomości położonej w Austrii nie będzie podlegało opodatkowaniu w Polsce. Natomiast majątek ruchomy podlega zasadniczo opodatkowaniu podatkiem spadkowym w tym państwie, którego obywatelem był spadkodawca w chwili swej śmierci ${ }^{27}$. Ustawodawca wskazał także przypadki, w których należy uwzględnić miejsce zamieszkania spadkodawcy i poddać opodatkowaniu majątek tam się znajdujący ${ }^{28}$. W tym przypadku należy dostrzec osobliwy związek reguły opodatkowania z zasadą domicylu.

Umowa pomiędzy Rzecząpospolitą Polską a Republiką Czeskosłowacką ${ }^{29}$ w sprawie zapobieżenia dwukrotnemu opodatkowaniu w dziedzinie podatków spadkowych została podpisana w Warszawie dnia 23 kwietnia 1925 r. ${ }^{30}$ Jej sukcesorem jest Republika Czeska. Reguła prawna zawarta w art. 1 umowy z 1925 r. stanowi, podobnie jak Konwencja z Austrią z 1927 r., że nieruchomy majątek spadkowy pozostały po obywatelach obu państw podlega opodatkowaniu podatkiem spadkowym tylko w tym państwie, w którym jest położony. W przypadku składników spadkowych niebędących nieruchomościami stosuje się regułę, według której majątek ten podlega opodatkowaniu w tym państwie, którego obywatelem był spadkodawca w chwili swej śmierci ${ }^{31}$. Jednak w sytuacji, kiedy spadkodawca posiadał w chwili swej śmierci miejsce zamieszkania w drugim państwie, majątek znajdujący się w tym państwie podlega w nim opodatkowaniu ${ }^{32}$. Umowa z 1925 r. w art. 2 ust. 2 zawiera definicję miejsca zamieszkania. W rozumieniu

\footnotetext{
24 Pisownia oryginalna.

25 Dz. U. z 1928 r. Nr 61, poz. 557.

26 Pisownia oryginalna.

27 Por. art. 2 pkt 1 lit. a Konwencji z dnia 24 listopada 1927 r.

28 Por. ibidem, art. 2 pkt 1 lit. b-c.

29 Pisownia oryginalna.

30 Dz. U. z 1926 r. Nr 13, poz. 78.

31 Por. art. 2 ust. 1 lit. a umowy z dnia 23 kwietnia 1925 r.

32 Por. ibidem, art. 2 ust. 1 lit. b.
} 
niniejszej umowy oznacza ono miejsce, w którym ktoś bądź posiada mieszkanie i stosownie do okoliczności należy przyjąć, że zamierza utrzymać je stale, bądź gdzie przebywa i stosownie do okoliczności należy przyjąć, że w tym miejscu albo w tym kraju nie zamierza przebywać tylko chwilowo. Reguła kolizyjna stosowana jest w sytuacji, w której spadkodawca posiadał w chwili swej śmierci miejsce zamieszkania w obydwu państwach, wówczas majątek spadkowy podlega opodatkowaniu w państwie, którego obywatelem był spadkodawca ${ }^{33}$.

Konwencja z dnia 12 maja 1928 r. między Rzecząpospolitą Polską a Królestwem Węgierskim w celu zapobieżenia podwójnemu opodatkowaniu spad-

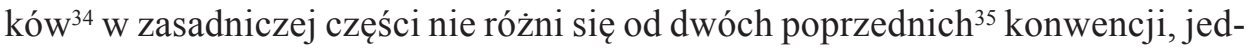
nak wprowadza ona nieliczne warunkowe odmienności. Reguła zapobiegająca podwójnemu opodatkowaniu nabywanych nieruchomości spadkowych określa sposób ich opodatkowania, według którego podlegają podatkowi spadkowemu tylko w tym kraju, w którym są położone, co jest klasycznym ujęciem tego typu regulacji. W przypadku nabycia części składowych spadku niebędących nieruchomościami zastosowanie mają reguły zawarte w art. 2 niniejszej Konwencji. Podobnie jak przedstawione wcześniej konwencje o unikaniu podwójnego opodatkowania, również i ta konstrukcja stosuje jako regułę generalną opodatkowanie majątku w tym państwie, którego obywatelem był zmarły w chwili swej śmierci. Aczkolwiek w przypadku, gdy zmarły w chwili swej śmierci posiadał miejsce zamieszkania w drugim państwie, to nabyty majątek tam zlokalizowany podlega opodatkowaniu $\mathrm{w}$ tym państwie ${ }^{36}$. Jednak w przypadku posiadania przez spadkodawcę miejsca zamieszkania w obu państwach, nabycie poszczególnych części spadkowych podlega opodatkowaniu jedynie w państwie, którego obywatelem był zmarły ${ }^{37}$. Konwencja z 1928 r. zawiera w art. 3 normy rozstrzygające o miejscu położenia części składowych spadku. Należy zaznaczyć, że dotychczasowymi czynnikami decydującymi o opodatkowaniu były osobliwe związki spadkodawcy z krajem, w którym posiadał miejsce zamieszkania lub którego był obywatelem. Ten stan rzeczy nie uwzględnia osoby nabywcy, na którym - zgodnie z obecnie obowiązującymi regułami dotyczącymi obowiązku podatkowego w ramach podatku od spadków i darowizn - ciąży obowiązek podatkowy ${ }^{38}$. Warunek ten znajduje wyraz w art. 2 lit. d Konwencji z 1928 r., zgodnie z którym, jeżeli w chwili śmierci zmarłego nabywca był obywatelem jednego z państw będących stronami Konwencji, wówczas obywatelstwo determinuje stosowanie reguły podatkowej dotyczącej opodatkowania nabywanego majątku spadkowego.

\footnotetext{
33 Por. ibidem, art. 2 ust. 1 lit. c.

34 Dz. U. z 1931 r. Nr 75, poz. 602.

35 Art. 1 Konwencji z dnia 12 maja 1928 r.

36 Por. ibidem, art. 2 lit. b.

37 Por. ibidem, art. 2 lit. c.

38 Por. art. 5 ustawy podatku od spadków i darowizn.
} 
Istotna reguła z zakresu przeciwdziałania podwójnemu opodatkowaniu znajduje swój wyraz w ograniczającej zakres opodatkowania podatkiem od spadków i darowizn instytucji wyłączenia. Oznacza ona, że obowiązek podatkowy w ramach podatku od spadków i darowizn nie powstaje. Stan normatywny ujęty w art. 3 pkt 1 podatku od spadków i darowizn posiada szczególne znaczenie w zakresie unikania podwójnego opodatkowania. Konstrukcja tego przepisu zakłada, że określone podmioty dokonujące wskazanych czynności na terytorium Rzeczypospolitej nie podlegają opodatkowaniu. Reguły dotyczące opodatkowania podatkiem od spadków i darowizn kreujące instytucje wyłączenia stosują zasadę, według której następuje przesunięcie przedmiotu opodatkowania z konstrukcji jednego podatku na rzecz innego. Zasada ta nazywana jest powszechnie przerzucalnością lub przesunięciem spod reżimu danej regulacji podatkowej na rzecz innej ${ }^{39}$, określając przez to granice źródeł przychodów. Jednak stan faktyczny ujęty w hipotezie art. 3 pkt 1 ustawy o podatku od spadków i darowizn nie znajduje wyrazu w pozostałych normach szczegółowego polskiego prawa podatkowego, co wskazuje na jego szczególny charakter.

Instytucja wyłączenia, objęta regułą normy prawnej w myśl art. 3 pkt 1 ustawy o podatku od spadków i darowizn, znajduje zastosowanie, jeżeli nabywca oraz spadkodawca lub darczyńca nie byli obywatelami polskimi i nie mieli miejsca stałego pobytu lub siedziby na terytorium Rzeczypospolitej Polskiej. Istotnie należy zauważyć, że decydujące znaczenie ma spełnienie warunków, do których zalicza się nieposiadanie miejsca stałego pobytu na terytorium RP i posiadanie obywatelstwa innego niż polskie. Warunki te muszą być spełnione łącznie przez wszystkie podmioty czynności. Powyższa reguła ma zastosowanie jedynie w przypadku nabycia rzeczy ruchomych znajdujących się na terytorium RP, wyłącznie w drodze spadku albo darowizny, co w istotny sposób zawęża zakres jej stosowania.

Pewne związki z zakresu unikania podwójnego opodatkowania należy dostrzec w zakresie stosowania zwolnień podatkowych, ujętych w art. 4 ust. 1 oraz art. 4a ustawy o podatku od spadków i darowizn. Pierwotna przesłanka do zastosowania instytucji zwolnień podatkowych w ramach podatku od spadków i darowizn znajduje swój wyraz w art. 4 ust. 4 ustawy o podatku od spadków $\mathrm{i}$ darowizn. Hipoteza tej normy prawnej zakłada spełnienie warunku w postaci posiadania przez nabywcę określonego obywatelstwa lub miejsca zamieszkania. Należy przy tym zaznaczyć, że choć taka norma obowiązuje, pozbawia ona możliwości korzystania z instytucji zwolnień podatkowych jedynie w sytuacjach incydentalnych. Mając na uwadze reguły ujęte w omawianym przepisie, podmiotami, wobec których stosowane będą regulacje z zakresu zwolnień podatkowych, są nabywcy będący obywatelami polskimi lub jednego z państw członkowskich Unii

39 Por. art. 2 ust. pkt 3 ustawy z dnia 26 lipca 1991 r. o podatku dochodowym od osób fizycznych, t.j. Dz. U. z 2012 r., poz. 361 ze zm. 
Europejskiej ${ }^{40}$ lub też państw członkowskich Europejskiego Porozumienia o Wolnych Handlu (EFTA) ${ }^{41}$, bądź osoby mające miejsce zamieszkania na terenie Rzeczypospolitej Polskiej lub na terytorium wymienionego państwa. W ten sposób szeroki zakres stosowania preferencyjnych regulacji jest ograniczony podmiotowo $z$ uwagi na posiadanie przez nabywcę określonego obywatelstwa lub miejsca zamieszkania ${ }^{42}$. Można zauważyć, iż w pewnych przypadkach niektóre podmioty będą zobligowane do zapłaty podatku, nawet na zasadach podwójnego opodatkowania, z kolei wskazane podmioty, spełniając jedynie przesłankę obywatelstwa, nie zapłacą podatku wcale. Ten stan rodzi pewne obawy związane z postrzeganiem w szeroko ujętej niesprawiedliwości podatkowej, jednak w tym przypadku posiadanie obywatelstwa państwa przynależnego do określonych struktur należy uznać za samą w sobie preferencję podatkową.

Podsumowując, należy stwierdzić, że przedstawione przykłady wskazują na znaczenie międzynarodowego prawa podatkowego w zakresie stosowania preferencji podatkowych. Przestrzeń stosowania preferencji podatkowych zawiera liczne określenia wykraczające poza krajowe prawo podatkowe. Nadmienić należy, że wiele preferencji podatkowych ograniczonych jest do terytorium Starego Kontynentu, mając na szczególnym względzie państwa członkowskie Unii Europejskiej. Nie bez znaczenia pozostaje fakt braku norm dotyczących zakresu unikania podwójnego opodatkowania w ramach podatku od spadków i darowizn. Ten stan wymaga reformy, mając na uwadze harmonizację prawa podatkowego w państwach Unii Europejskiej. Występująca w ustawie o podatku od spadków i darowizn ulga, w postaci możliwości zaliczenia w poczet ciężarów zmniejszających podstawę opodatkowania podatku zapłaconego za granicą, istotnie nie spełnia właściwej roli, ponieważ konstrukcja prawna polegająca na możliwości zmniejszenia kwoty podatku od spadków i darowizn o kwotę podatku zapłaconego za granicą efektywniej spełniałaby funkcje preferencji podatkowej. Warto zaznaczyć, że w tym przypadku powstałby stan rzutujący na zmniejszenie dochodów gmin, co w dobie ogólnego kryzysu oraz sztywnych reguł wydatkowych jednostek samorządu terytorialnego stanowi dla nich istotny czynnik.

${ }^{40}$ Państwami członkowskimi Unii Europejskiej są: Austria, Belgia, Bułgaria, Cypr, Czechy, Dania, Estonia, Finlandia, Francja, Grecja, Hiszpania, Holandia, Irlandia, Litwa, Luksemburg, Łotwa, Malta, Niemcy, Polska, Portugalia, Rumunia, Słowacja, Słowenia, Szwecja, Węgry, Wielka Brytania, Włochy.

${ }^{41}$ Członkami EFTA są: Islandia, Liechtenstein, Norwegia, Szwajcaria.

${ }^{42}$ Por. art. 4 ust. 4 ustawy podatku od spadków i darowizn. 